\title{
MANGANESE AND ZINC LEAF APPLICATION ON COMMON BEAN GROWN ON A "CERRADO” SOIL
}

\author{
Itamar Rosa Teixeira $^{1}$; Aluízio Borém ${ }^{1 *}$; Geraldo Antônio de Andrade Araújo ${ }^{1}$; Renildes Lúcio \\ Ferreira Fontes ${ }^{2}$ \\ ${ }^{1}$ UFV, Depto. de Fitotecnia - 36570-000 - Viçosa, MG - Brasil. \\ ${ }^{2}$ UFV, Depto. de Solos. \\ *Corresponding author <borem@ufv.br>
}

\begin{abstract}
The occurrence of micronutrient deficiencies, mainly of manganese (Mn) and zinc ( $\mathrm{Zn})$ in "cerrado" soils, has been increasing in several crops, including bean. Such a problem is caused by high rates of liming material applied entirely on the soil surface. In this study, the effects of the leaf application of Mn and $\mathrm{Zn}$ rates were evaluated. Three experiments were carried out: two in greenhouse and one under field conditions. The greenhouse experiments were set up using a randomized block design and a 5 x 5 factorial, with three replicates, consisting of five rates of $\mathrm{Mn}\left(0,75,150,300\right.$, and $\left.600 \mathrm{~g} \mathrm{ha}^{-1}\right)$ and five rates of $\mathrm{Zn}(0$, $50,100,200$, and $400 \mathrm{~g} \mathrm{ha}^{-1}$ ) applied via leaves at the $25^{\text {th }}$ day, or both alternatively parceled at 25 and 35 days after emergency (DAE), respectively, for the first and second experiments. In the field experiment, a randomized block design was used with four replicates, and the same treatments as those used in the greenhouse. Leaf applications performed at 25 and 35 DAE were efficient in correcting the symptoms of the Mn and $\mathrm{Zn}$ deficiencies. The combined application of $\mathrm{Mn}$ and $\mathrm{Zn}$ caused an increase in plant height, primary yield components as number of grains per pod, number of pods per plant, and productivity itself. The maximum technical efficiency was obtained with $315 \mathrm{~g} \mathrm{ha}^{-1} \mathrm{Mn}$ and $280 \mathrm{~g} \mathrm{ha}^{-1} \mathrm{Zn}$ for a bean productivity of $2.275 \mathrm{~kg} \mathrm{ha}^{-1}$, corresponding to $60 \%$ above control.
\end{abstract}

Key words: Phaseolus vulgaris, yield, mineral nutrition, micronutrients

\section{FEIJOEIRO EM SOLO DE CERRADO SUBMETIDO A DOSES DE MANGANÊS E ZINCO VIA FOLIAR}

\begin{abstract}
RESUMO: Em solos de cerrado tem sido cada vez mais freqüente o surgimento de casos de deficiência de micronutrientes em diversas culturas, incluindo o feijoeiro, com destaque para manganês (Mn) e zinco (Zn), o que é ocasionado pelas elevadas dosagens de corretivo utilizadas em aplicações de superfície e sem incorporação adequada. Este trabalho avaliou o efeito de doses de Mn e Zn via foliar em feijoeiros cultivados em solo de cerrado. Foram conduzidos três experimentos, sendo dois em casa de vegetação e um em campo. Os experimentos de casa de vegetação foram instalados seguindo o delineamento de blocos ao acaso, num esquema fatorial 5 x 5, com três repetições, envolvendo cinco doses de $\mathrm{Mn}\left(0,75,150,300\right.$ e $\left.600 \mathrm{~g} \mathrm{ha}^{-1}\right) \mathrm{e}$ cinco doses de $\mathrm{Zn}\left(0,50,100,200 \mathrm{e} 400 \mathrm{~g} \mathrm{ha}^{-1}\right)$ aplicadas via foliar, aos $25 \mathrm{ou}$, alternativamente, ambas parceladas aos 25 e 35 dias após emergência (DAE), respectivamente, no primeiro e segundo experimento. No experimento de campo empregou-se o delineamento em blocos casualizados, com quatro repetições com os mesmos tratamentos usados em casa de vegetação. Duas aplicações foliares, efetuadas aos 25 e 35 DAE foram eficientes na correção dos sintomas de deficiência de Mn e Zn. A aplicação conjunta de Mn e Zn aumentou a altura de planta, os componentes primários de rendimento, o número de grãos por vagem, o número de vagens por planta e a produtividade "per se". A máxima eficiência técnica foi obtida com $315 \mathrm{~g} \mathrm{ha}^{-1}$ de Mn e $280 \mathrm{~g} \mathrm{ha}^{-1}$ de $\mathrm{Zn}$, para uma produtividade de $2.275 \mathrm{~kg} \mathrm{ha}^{-1}$ de grãos, correspondente a $60 \%$ acima da testemunha.

Palavras-chave: Phaseolus vulgaris, rendimento, nutrição mineral, micronutrientes
\end{abstract}

\section{INTRODUCTION}

Bean crop in Brazil is no longer a subsistence crop, but a rather profitable crop with high productivity indices, mainly in the "cerrado" areas. However, the use of recommended liming method that overestimates the amount of limestone, as well as its application by superficial incorporation, has caused serious nutritional prob- lems related to micronutrient deficiencies, especially manganese (Mn) and zinc ( $\mathrm{Zn})$. In the case of $\mathrm{Zn}$, the situation becomes even worse because of its low contents in soils. Zinc, boron and molybdenum are the micronutrients receiving the greatest attention of researchers. However, according to literature reports (Mello, 1990; Silveira et al., 1996; Scaramuzza, 1998; Lima et al., 1999), results are still controversial. Most studies of manganese are con- 
cerned to toxicity. In recent years, however, the cases of Mn deficiency have appeared in several crops grown in "cerrado" soils, such as soybean (Abreu et al., 1996; Oliveira Jr. et al., 2000; Mann et al., 2001), cotton (Rosolem \& Ferelli, 2000), rice (Pereira et al., 2001), and bean (Marinho et al., 1998; Kikuti et al., 1998). For soybean, the application of $\mathrm{Mn}$ on deficient soils is recommended, and a rate of $350 \mathrm{~g} \mathrm{ha}^{-1}$ via leaves is preconized (Embrapa, 2001).

Foliar fertilization is an effective practice for the application of some micronutrients, since it uses low rates and the micronutrient does not directly contact the soil, avoiding losses through fixation (Volkweiss, 1991). However, the narrow limit between phytotoxicity and deficiency brings the need for defining appropriate rates to be used.

There is a lack of information on $\mathrm{Mn}$ and $\mathrm{Zn}$ in a "cerrado" soils cropped with beans. Therefore, this study investigates effects of $\mathrm{Mn}$ and $\mathrm{Zn}$ rates applied via leaves to bean plants grown on a "cerrado" soil, under greenhouse or field conditions.

\section{MATERIAL AND METHODS}

Three experiments were carried out, two under greenhouse and one under field conditions. Those under greenhouse conditions were conducted in Viçosa, MG, using a Typic distrustox, "cerrado" phase, from a bean producing area located in Ijaci-MG, Brazil, $\left(21^{\circ} 14^{\prime} \mathrm{S}, 45^{\circ} 00^{\prime} \mathrm{W}\right.$; altitude $\left.805 \mathrm{~m}\right)$. The soil was collected at the $0-20 \mathrm{~cm}$ layer, and its chemical analysis shows the following results: $\mathrm{pH}$ in $\mathrm{H}_{2} \mathrm{O}(1: 2.5)=6.9$; available $\mathrm{P}$ (Mehlich-1) $=3.0 \mathrm{mg} \mathrm{dm}{ }^{-3} ; \mathrm{K}^{+}$(Mehlich-1) $=56 \mathrm{mg} \mathrm{dm}{ }^{-3} ; \mathrm{Ca}^{+2}\left(\mathrm{KCl} 1 \mathrm{~mol} \mathrm{~L}^{-1}\right)=43 \mathrm{mmol}_{\mathrm{c}} \mathrm{dm}^{-3}$; $\mathrm{Mg}^{+2}\left(\mathrm{KCl} 1 \mathrm{~mol} \mathrm{~L}^{-1}\right)=10 \mathrm{mmol}_{\mathrm{c}} \mathrm{dm}^{-3} ; \mathrm{Al}^{+3}\left(\mathrm{KCl}^{\mathrm{c}} 1 \mathrm{~mol}\right.$ $\left.\mathrm{L}^{-1}\right)=0.0 \mathrm{mmol}_{\mathrm{c}} \mathrm{dm}^{-3} ; \mathrm{B}$ (hot water) $=0.6 \mathrm{mg} \mathrm{kg}^{-1} ; \mathrm{Cu}$ $($ DTPA $)=0.8 \mathrm{mg} \mathrm{kg}^{-1} ; \mathrm{Fe}($ DTPA $)=10 \mathrm{mg} \mathrm{kg}^{-1} ; \mathrm{Mn}$ $($ DTPA $)=1.0 \mathrm{mg} \mathrm{kg}^{-1}$; and Zn $($ DTPA $)=0.5 \mathrm{mg}$ soil $\mathrm{kg}^{-1}$. A randomized block experimental design with three replicates in a $5 \times 5$ factorial scheme was used. Treatments consisted of five rates of $\operatorname{Mn}(0,75,150$, 300 and $\left.600 \mathrm{~g} \mathrm{ha}^{-1}\right)$ and five rates of $\mathrm{Zn}(0,50,100,200$ and $400 \mathrm{~g} \mathrm{ha}^{-1}$ ) sprayed on leaves at either one single application 25 days after emergence (DAE), or alternatively split at 25 and $35 \mathrm{DAE}$, in the first and second experiments, respectively. Manganese sulphate and zinc sulphate were used as nutrient sources in solution, corresponding to $300 \mathrm{~L} \mathrm{ha}^{-1}$. Data of the first experiment will not be shown because of the occurrence of phytotoxides in treatments of the highest rates, and deficiency in plants receiving the lowest rates of $\mathrm{Mn}$ and $\mathrm{Zn}$.

Each plot consisted of a plastic, $2.5 \mathrm{~kg}$ soil capacity pot, to which a basic fertilization solution modified from Malavolta (1980) was added. The following rates were evenly distributed and homogenized in the soil: $300 \mathrm{mg} \mathrm{dm}^{-3} \mathrm{~N}$ (urea); $200 \mathrm{mg} \mathrm{dm}^{-3} \mathrm{P}_{2} \mathrm{O}_{5}$ (simple superphosphate); $150 \mathrm{mg} \mathrm{dm}^{-3} \mathrm{~K}_{2} \mathrm{O}$ (potassium chloride); 0.5 $\mathrm{mg} \mathrm{dm}{ }^{-3} \mathrm{~B}$ (boric acid); $1.5 \mathrm{mg} \mathrm{dm}^{-3} \mathrm{Cu}$ (copper sulphate); $5 \mathrm{mg} \mathrm{dm}^{-3} \mathrm{Fe}$ (iron-EDTA); and $0.1 \mathrm{mg} \mathrm{dm}^{-3} \mathrm{Mo}$ (ammonium molybdate ). The rates of $\mathrm{N}$ and $\mathrm{K}$ were parceled, and half was applied at planting time and the other half at 20 DAE. The bean cultivar 'Pérola' was used, which has the following characteristics: typical 'carioca' grains; uncertain growth habit, type II/III (from semi-erect to prostrate), medium cycle and resistance to the angular-spot, leaf blight and common-mosaic (Embrapa, 1998).

Irrigation was performed daily with deionized water to keep moisture close to soil saturation. In both experiments, a minimal infestation of the mining larvae (Liriomyza sp.) was observed on primary leaves, but did not require control. Two plants were kept in each plot: one of them harvested at flowering, for evaluation of dry matter yield of stalks, branches and leaves, whereas the other was harvested at the physiologic maturation, when number of pod per plant, number of grain per pod, dry matter yield of stalks and branches, leaves, pods and grains were evaluated.

The field experiment was carried out at the same place where the soil was collected for the greenhouse experiments, with the same cultivar and scheme treatments described for the greenhouse experiments, in a randomized block design, with four replicates, 5 x 5 factorial scheme. Two $\mathrm{Mn}$ and $\mathrm{Zn}$ foliar applications were performed at 25 and 35 DAE. The nutrient sources and application procedures were similar to those used in the greenhouse experiments.

Each plot consisted of four, $5 \mathrm{~cm}$-long rows, spaced $0.50 \mathrm{~cm}$, total area of $10 \mathrm{~m}^{2}$ with effective area of $5 \mathrm{~m}^{2}$, corresponding to two central rows. The soil was prepared in a conventional way, with one plowing and two harrowings; liming was not necessary. The basic fertilization consisted of $20 \mathrm{~kg} \mathrm{ha}^{-1}$ urea $(\mathrm{N}), 100 \mathrm{~kg} \mathrm{ha}^{-1} \mathrm{P}_{2} \mathrm{O}_{5}$ (simple superphosphate) and $60 \mathrm{~kg} \mathrm{ha}^{-1} \mathrm{~K}_{2} \mathrm{O}$ (potassium chloride). The insecticide forate was applied with the fertilizers at sowing to prevent the first pest of the bean plant. The $\mathrm{N}$ application was made by hand at $20 \mathrm{DAE}$, using ammonium sulphate at the rate of $200 \mathrm{~kg} \mathrm{ha}^{-1}$ (40 $\mathrm{kg} \mathrm{ha}^{-1} \mathrm{~N}$ ), applied in a continuous line alongside plants. Sowing was accomplished manually and about $90 \%$ of the plantlets had emerged after six days. There was a need for controlling ants by the time of plantlet emergency. A small infestation of Empoascab kraemeri and Maruca testutalis were also observed. They were controlled by the insecticides monocrotophos and deltamethrin, respectively. A widespread incidence of anthracnose also occurred at the end of the cycle, but no control was made. All other management practices usually used for bean cropping were performed. 
The following agronomic characteristics were evaluated: bean yield, yield components (number of pod per plant, number of grain per pod, and one-hundred grain mass), final stand and height of the plants. To evaluate results the surface response methodology was used, and the choice of the models was based on significances of regressions, considering the $t$ test at $5 \%$, and coefficients of determination.

\section{RESULTS AND DISCUSSION}

\section{Greenhouse experiment}

At the flowering stage, rates of Mn affected yield of dry matter in stalks and branches $(P<0.05)$, and dry matter of leaves was affected by the rates of both $\mathrm{Mn}$ and $\mathrm{Zn}(P<0.05)$, but not their interactions $(P>0.05)$. At the maturation stage, bean yield and yield components number of pod per plant, and number of grain per pod were affected by rates of either $\mathrm{Mn}$ and $\mathrm{Zn}$ and their interactions $(P>0.05)$; however, no influence of the treatments was found on dry matter yield of stalks and branches, leaves and pods $(P=0.05)$.

The best adjustment of data on dry matter in stalks and branches at the flowering stage was obtained through a quadratic model (Figure 1a). Data for dry matter in the leaves at the flowering stage and for grains at maturation, as well as the number of pod per plant and the number of grain per pod were adjusted to response surfaces by a quadratic model, in which Mn was always more contrasting. For this reason, the presentation of the effect of $\mathrm{Mn}$ rates within each rate of $\mathrm{Zn}$ was chosen.

The highest average value for stalk and branch dry matter produced was $2.53 \mathrm{~g}$ plant $^{-1}$, obtained at the full flowering stage at the rate of $328 \mathrm{~g} \mathrm{ha}^{-1} \mathrm{Mn}$ (Figure 1b). The foliar fertilization lead to an increase of $32 \%$ of dry matter in relation to the control. At the flowering stage, the lowest value of leaf dry matter $\left(2.08 \mathrm{~g}\right.$ plant $\left.^{-1}\right)$ was observed for the control (Figure 1b), while the highest (3.60 g plant ${ }^{-1}$ ), was observed for the combination of $332 \mathrm{~g} \mathrm{ha}^{-1}$ Mn with $237 \mathrm{~g} \mathrm{ha}^{-1} \mathrm{Zn}$, corresponding to an average increase of $73 \%$ in the production of the leaf dry matter in relation to the control. This result corroborates to the effectiveness of the treatments including two foliar applications.

The foliar application of the $\mathrm{Mn}$ and $\mathrm{Zn}$ rates affected the number of pod per plant and number of grain per pod. The addition of 300 and $255 \mathrm{~g} \mathrm{ha}^{-1} \mathrm{Mn}$ and $\mathrm{Zn}$, respectively, lead to a maximum of 10.6 pods per plant, which is $51 \%$ superior to the control. (Figure 1d). The highest value for number of grain per pod was 5.3, corresponding to an increase of $17 \%$ in relation to the control (Figure 1c). The number of pod per plant was the yield component that most affected bean yield, similarly to other research results (Lima et al., 1999; Teixeira et al., 2000).
Concerning to grain dry matter, the rate of $300 \mathrm{~g}$ $\mathrm{ha}^{-1} \mathrm{Mn}$ combined with $255 \mathrm{~g} \mathrm{ha}^{-1} \mathrm{Zn}$, resulted in the maximum grain mass (16.53 $\mathrm{g} \mathrm{plant}^{-1}$ ) (Figure 1e). This value was $64 \%$ superior to the control (Figure 1e), and is close to those observed in other experiments carried out under greenhouse conditions (Alvarenga, 1995; Lima, 1997).

Under $\mathrm{Mn}$ and $\mathrm{Zn}$ deficiencies, as those found in the present experiment, the parceled supplying of these elements at the vegetative phase and at the beginning of the reproductive phase is fundamental for the establishment of a better correction of the nutritional state of the plant. The increment on dry matter yield, observed in different organs of the bean plant, is related to the participation of both micronutrients in the photosynthesis process, nitrogen metabolism, auxin precursors, and several other enzymatic reactions, where they are required as cofactors (Marschner, 1995; Malavolta et al., 1997).

\section{Field experiment}

Bean yield, number of pod per plant, number of grain per pod, and plant height were affected by the foliar fertilization with $\mathrm{Mn}$ and $\mathrm{Zn}(P<0.05)$, while no $(P>0.05)$ differences were found for the final stand and the one-hundred grain mass. The final average stand was 11.3 plants per linear meter, considered normal for this crop. A quadratic response occurred for number of pod per plant with the effects of $\mathrm{Zn}$, and $\mathrm{Mn}$ in particular (Figure $2 \mathrm{c}$ ). The highest value of number of pod per plant was 7.9 , obtained with $340 \mathrm{~g} \mathrm{ha}^{-1} \mathrm{Mn}$ combined with $270 \mathrm{~g}$ $\mathrm{ha}^{-1} \mathrm{Zn}$. Using $\mathrm{Mn}$ alone promoted an increase of $22 \%$ in number of pod per plant, while an increment of $18 \%$ was obtained by the $\mathrm{Zn}$ fertilization. According to several studies, this yield component is the one presenting the highest correlation with bean yield (Lima et al., 1999; Teixeira et al., 2000), and may be related to the similarity between the regression curves of both variables in this study (Figures $2 \mathrm{c}$ and 2d).

Number of grains per pod was affected by the fertilization with $\mathrm{Mn}$ and $\mathrm{Zn}$, with a stronger contrast for Mn (Figure 2b). In Figure 2b, it cause observed a quadratic behavior of the $\mathrm{Mn}$ and $\mathrm{Zn}$ rates in relation to number of grain per pod, and the highest value of 6.1 was obtained for the combination of $330 \mathrm{~g} \mathrm{ha}^{-1} \mathrm{Mn}$ with $272 \mathrm{~g} \mathrm{ha}^{-1} \mathrm{Zn}$. Unlikely the effects observed for number of pod per plant and number of grain per pod, the supply of $\mathrm{Mn}$ and $\mathrm{Zn}$ did not affect the mass of one-hundred grains, which had an average value of $24.70 \mathrm{~g}$. The plant height was influenced by the addition of $\mathrm{Mn}$ and $\mathrm{Zn}$, with a more contrasting result for $\mathrm{Zn}$ (Figure 2a). This effect was expected, since $\mathrm{Zn}$ is an essential element for the synthesis of tryptophan, a precursor of the indoleacetic acid (AIA), a plant hormone that promotes growth (Marschner, 1995; Malavolta et al., 1997). There was a quadratic behavior of the $\mathrm{Mn}$ and $\mathrm{Zn}$ rates concerning plant height, 
with the highest value $(48.18 \mathrm{~cm})$ observed for the combination of $257 \mathrm{~g} \mathrm{ha}^{-1} \mathrm{Zn}$ with $335 \mathrm{~g} \mathrm{ha}^{-1} \mathrm{Mn}$. Above these rates, there was a decrease in the height of the plants, probably because of phytotoxicity.

The bean yield was affected by the foliar fertilization with $\mathrm{Mn}$ and $\mathrm{Zn}$. The maximum technical efficiency (MET) was reached to the rate of $315 \mathrm{~g} \mathrm{ha}^{-1} \mathrm{Mn}$ combined with $280 \mathrm{~g} \mathrm{ha}^{-1} \mathrm{Zn}$, corresponding to the maximum grain productivity of $2.275 \mathrm{~kg} \mathrm{ha}^{-1}$ (Figure $2 \mathrm{~d}$ ). The combined application of $\mathrm{Mn}$ and $\mathrm{Zn}$ at the MET rate provided an increase of $60 \%$ in productivity, in relation to the control $\left(1.425 \mathrm{~kg} \mathrm{ha}^{-1}\right)$. However, the application of only $315 \mathrm{~g} \mathrm{ha}^{-1} \mathrm{Mn}$ provided a productivity of 1.905 $\mathrm{kg} \mathrm{ha}^{-1}$, an increase of $34 \%$. On the other hand, the application of only $280 \mathrm{~g} \mathrm{ha}^{-1} \mathrm{Zn}$ lead to an increase of $26 \%$ in bean productivity that reached $1.795 \mathrm{~kg} \mathrm{ha}^{-1}$. It is thus evident that manganese and zinc are very important elements in the nutrition of the bean crop in the soils of "cerrado" areas that are deficient in these micronutrients.
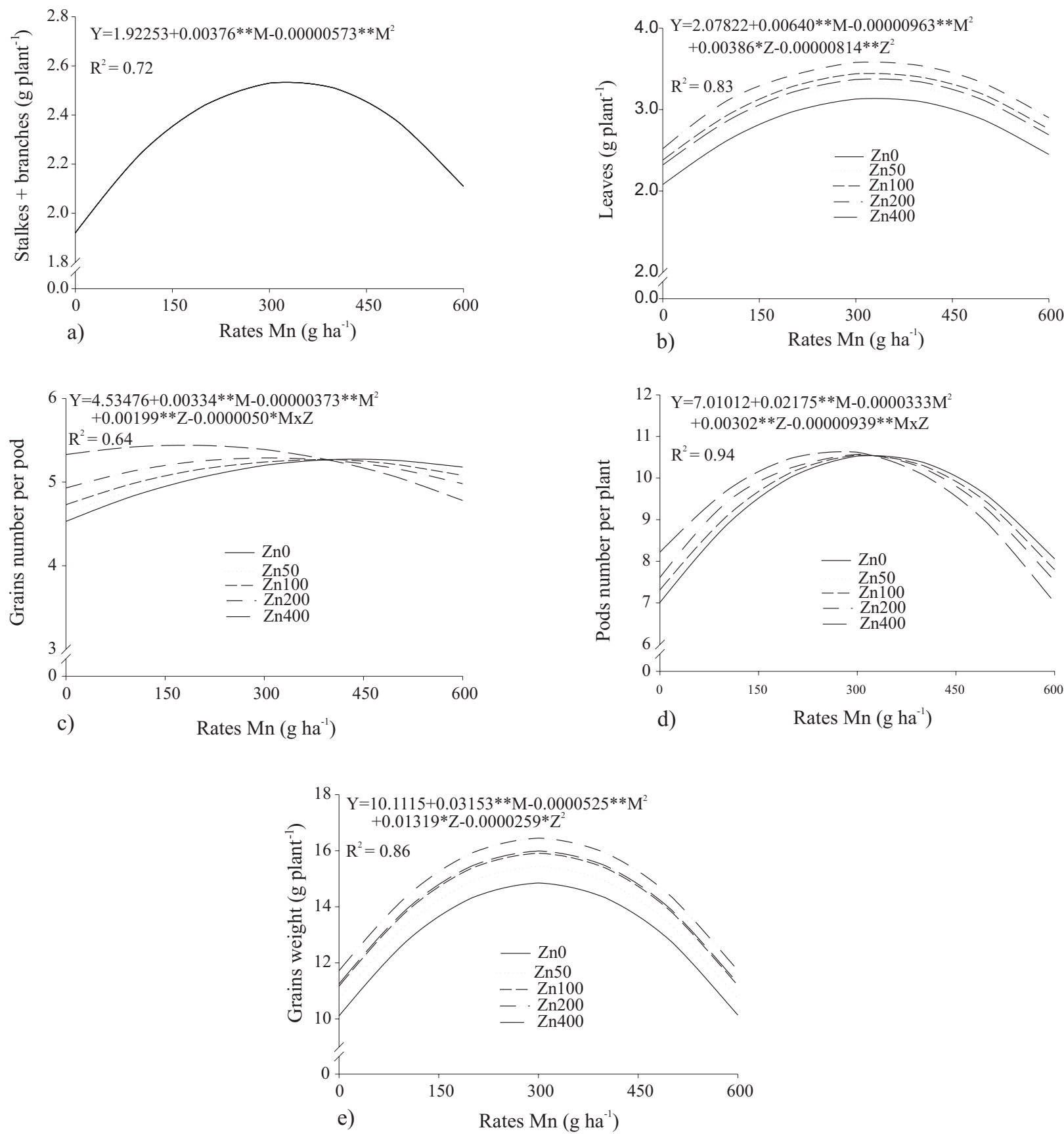

Figure 1 - Estimates of dry matter yield of stalks and branches (a) and leaves (b) at flowering, and of the number of grain per pod (c) and number of pod per plant (d) and grain mass per plant (e) for beans submitted to foliar application of different rates of Mn and $\mathrm{Zn}$, under greenhouse conditions. 

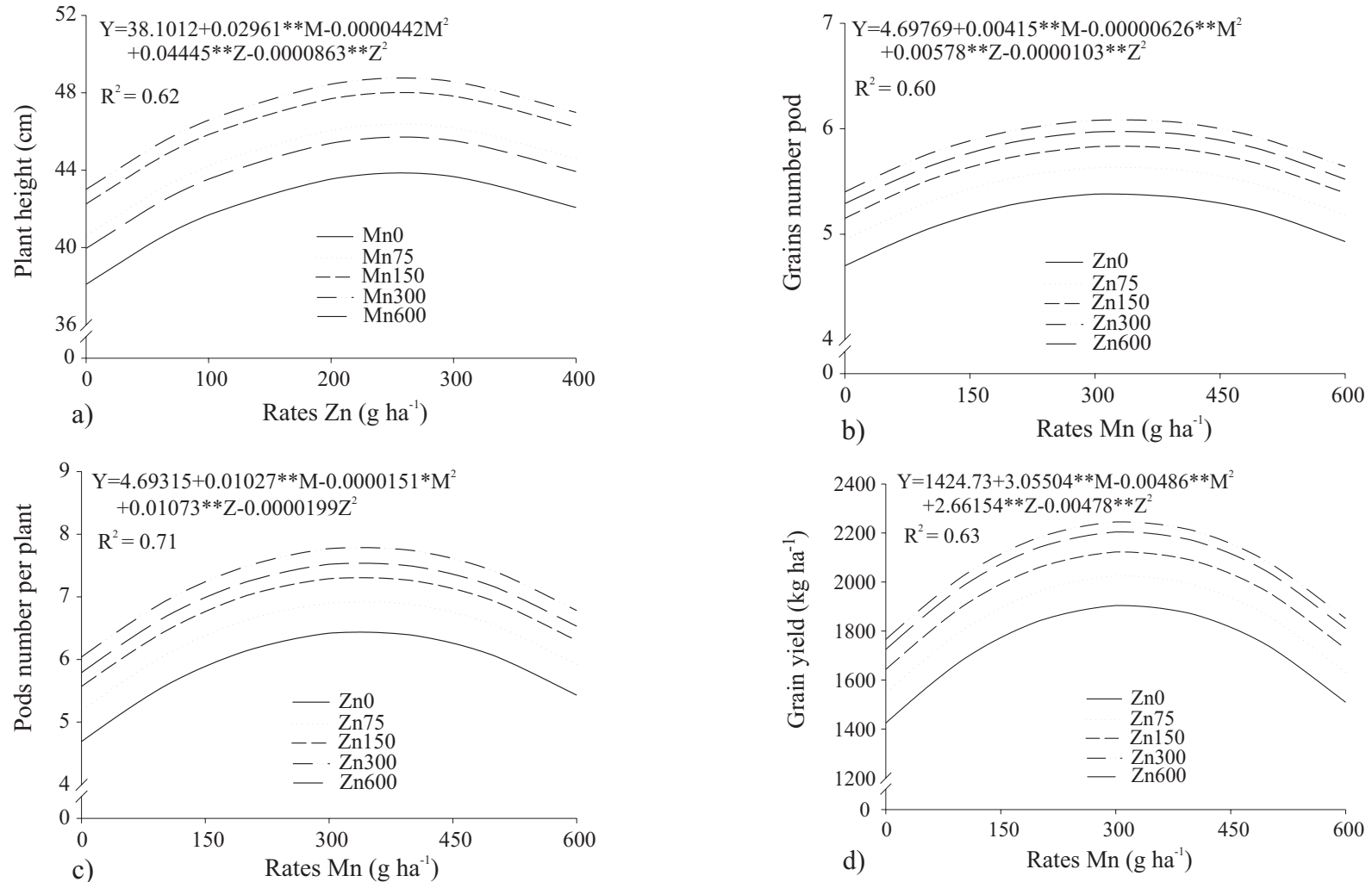

Figure 2 - Estimates of plant height (a), number of grain per pod (b), number of pod per plant (c) and bean grain yield (d) for beans submitted to foliar application at different rates of manganese and zinc, under field conditions.

\section{REFERENCES}

ABREU, C.A.; RAIJ, B. van.; TANAKA, R.T. Fontes de manganês para soja e seus efeitos na análise de solo. Revista Brasileira de Ciência do Solo, v.20, p.91-97, 1996.

ALVARENGA, P.E. Resposta do feijoeiro (Phaseolus vulgaris L.) às adubações nitrogenada e molìbdica e à inoculação com Rhizobium leguminosarum bv. phaseoli. Lavras: Universidade Federal de Lavras, 1995. 67p. (Dissertação - Mestrado).

EMPRESA BRASILEIRA DE PESQUISA AGROPECUÁRIA. Informativo anual das Comissões Regionais de Feijão: cultivares de feijão recomendadas para o plantio no ano agrícola 1998/1999. Goiânia: EMBRAPA, CNPAF, 1998. 29p.

EMPRESA BRASILEIRA DE PESQUISA AGROPECUÁRIA. Tecnologia de produção de soja: Região Central do Brasil. Londrina: Embrapa Soja, 2001. 267p. (Documento, 167).

KIKUTI, H.; TEIXEIRA, I.R.; MARINHO, J.T.S.; CARVALHO, J.G.; ANDRADE, M.J.B. Efeito do manganês na produção da matéria seca das cultivares de feijão Pérola e Carioca na época do florescimento. In: FERTIBIO, 1., Caxambú, 1998. Anais. Lavras: UFLA, 1998. p.711.

LIMA, S.F. Comportamento do feijoeiro (Phaseolus vulgaris L.) submetido à aplicação foliar de doses de boro, molibdênio, e zinco. Lavras: Universidade Federal de Lavras, 1997. 76p. (Dissertação - Mestrado).

LIMA, S.F.; ANDRADE, M.J.B.; CARVALHO, J.G. Resposta do feijoeiro à adubação foliar de boro, molibdênio e zinco. Ciência e Agrotecnologia, v.23, p.462-467, 1999.

MALAVOLTA, E. Elementos de nutrição mineral de plantas. São Paulo: Agronômica Ceres, 1980. 251p.

MALAVOLTA, E.; VITTI, G.C.; OLIVEIRA, S.A. Avaliação do estado nutricional das plantas; princípios e aplicações. 2.ed. Piracicaba: POTAFOS, 1997. 319p.

MANN, E.N.; REZENDE, P.M.; CARVALHO, J.G.; CORRÊA, J.B.D. Efeito da adubação com manganês, via solo e foliar em diferentes épocas na cultura da soja. Ciência e Agrotecnologia, v.25, p.264-273, 2001.
MARINHO, J.T.S.; TEIXEIRA, I.R.; KIKUTI, H.; CARVALHO, J.G.; ANDRADE, M.J.B. Resposta das cultivares de feijão Pérola e Carioca à doses de manganês. In: FERTIBIO, 1., Caxambú, 1998. Anais. Lavras: UFLA, 1998. p.710.

MARSCHNER, $H$. Mineral nutrition of higher plants. 2.ed. San Diego: Academic Press, 1995. 889p.

MELLO, E.F.R.Q. Resposta de cultivares de feijão (Phaseolus vulgaris L.) a níveis de zinco nas formas inorgânicas e orgânicas em casa de vegetação e no campo. Curitiba: Universidade Federal do Paraná, 1990. 125p. (Dissertação - Mestrado).

OLIVEIRA JR., J.A.; MALAVOLTA, E.; CABRAL, C.P. Efeito do manganês sobre a soja cultivada em solo de cerrado do triângulo mineiro. Pesquisa Agropecuária Brasileira, v.35, p.1629-1636, 2000.

PEREIRA, G.D.; BERTONI, J.C.; CARVALHO, J.G.; MORAIS, A.R. Doses e modos de adubação com manganês e seus efeitos na produção da cultura do arroz. Revista Brasileira de Ciência do Solo, v.25, p.625-633, 2001.

ROSOLEM, C.A.; FERELLI, L. Resposta diferencial de cultivares de algodão ao manganês em solução nutritiva. Revista Brasileira de Ciência do Solo, v.24, p.355-361, 2000.

SCARAMUZZA, J.F. Produtividade de grãos e teores foliares de nutrientes em feijoeiro (Phaseolus vulgaris L.) em resposta à aplicação de boro, zinco, e cobre, via foliar ou no sulco. Viçosa: UFV, 1998. 79p. (Tese Doutorado).

SILVEIRA, P.M.; DYNIA, J.F.; ZIMMERMANN, F.J.P. Resposta do feijoeiro irrigado a boro, zinco e molibdênio. Ciência e Agrotecnologia, v.20, p.198-204, 1996.

TEIXEIRA, I.R.; ANDRADE, M.J.B.; CARVALHO, J.G.; MORAIS, A.R.; CORRÊA, J.B.D. Resposta do feijoeiro (Phaseolus vulgaris L. cv. Pérola) a diferentes densidades de semeadura e doses de nitrogênio. Ciência e Agrotecnologia, v.24, p.399-408, 2000.

VOLKWEISS, S.J. Fontes e métodos de aplicação. In: FERREIRA, M.E.; CRUZ, M.C.P. Micronutrientes na agricultura. Piracicaba: POTAFOS CNPq, 1991. p.391-412.

Received October 01,2002

Accepted November 13, 2003 